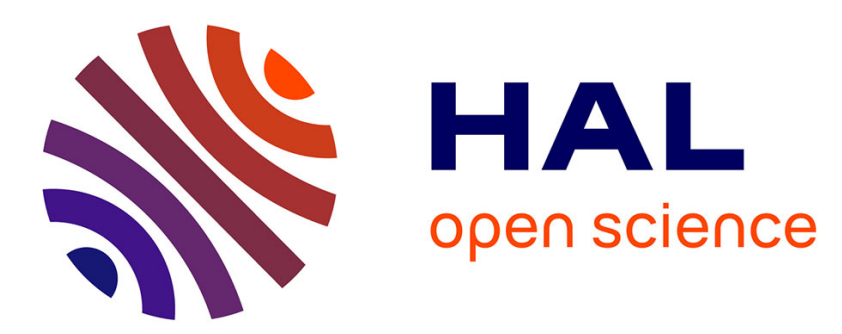

\title{
Introducing nests of the oil-collecting bee Centris analis (Hymenoptera: Apidae: Centridini) for pollination of acerola (Malpighia emarginata) increases yield
}

Celso Magalhães, Breno Freitas

\section{- To cite this version:}

Celso Magalhães, Breno Freitas. Introducing nests of the oil-collecting bee Centris analis (Hymenoptera: Apidae: Centridini) for pollination of acerola (Malpighia emarginata) increases yield. Apidologie, 2013, 44 (2), pp.234-239. 10.1007/s13592-012-0175-4 . hal-01201292

\section{HAL Id: hal-01201292 \\ https://hal.science/hal-01201292}

Submitted on 17 Sep 2015

HAL is a multi-disciplinary open access archive for the deposit and dissemination of scientific research documents, whether they are published or not. The documents may come from teaching and research institutions in France or abroad, or from public or private research centers.
L'archive ouverte pluridisciplinaire HAL, est destinée au dépôt et à la diffusion de documents scientifiques de niveau recherche, publiés ou non, émanant des établissements d'enseignement et de recherche français ou étrangers, des laboratoires publics ou privés. 


\title{
Introducing nests of the oil-collecting bee Centris analis (Hymenoptera: Apidae: Centridini) for pollination of acerola (Malpighia emarginata) increases yield
}

\author{
Celso B. Magalhães, Breno M. Freitas \\ Departamento de Zootecnia, Universidade Federal do Ceará-UFC, CCA, Campus Universitário do Pici, Bloco 808, \\ 60356-000 Fortaleza, CE, Brazil
}

Received 5 July 2012 - Revised 1 October 2012 - Accepted 12 October 2012

\begin{abstract}
This study aimed to test the feasibility and effectiveness of introducing trap nests inhabited by the oilcollecting bee Centris (Heterocentris) analis on increasing productivity of organic orchards of acerola (Malpighia emarginata). Trap nest blocks containing 242 nests of $C$. analis were placed on the border of 22 orchards of four acerola varieties and monitored over the blooming season. Results were compared to other 22 orchards without bee introduction and showed an increment of $62 \%$ in the number of trap nests inhabited by C. analis and acerola yield was significantly higher in the orchards where bees were introduced, independently of variety. The increase in productivity was $1,798 \mathrm{~kg} / \mathrm{ha}$. It was concluded that the introduction of inhabited nests of C. analis to acerola orchards allows multiplying populations of $C$. analis; to increase the number of bees and to reduce pollination deficits in acerola orchards; and can provide real gains in productivity of acerola commercial plantations.
\end{abstract}

bee rearing / crop pollination / pollination deficit / solitary bees / trap nests

\section{INTRODUCTION}

Despite the worldwide existence of a thriving business of rearing and hiring bees for pollination of some crops, this industry is mostly focused on a few social bee species such as Apis melifera Linnaeus and Bombus spp. that are generalists, can be produced in large numbers, and accepts hives that can easily be transported in and out of orchards (Free 1993). The use of solitary bees for pollination is less common and usually restricted to morphological or behavioral specialization between flower and bee spe-

Electronic supplementary material The online version of this article (doi:10.1007/s13592-012-0175-4) contains supplementary material, which is available to authorized users.

Corresponding author: B.M. Freitas, freitas@ufc.br Manuscript editor: Stan Schneider cies, such as those observed between Osmia spp. and the family Rosaceae, Xylocopa spp. and Passifloraceae and Megachile rotundata Fabricius and Nomia melanderi Cockerell and alfalfa (Medicago sativa Linnaeus) (Roubik 1992; Free 1993; Vicens and Bosch 2000). Close bee-plant pollination relationships have also been demonstrated to other groups of solitary bees such as Peponapis spp. and curcubits, euglossine bees and orchids, and Centridini bees and oil-producing species of Malpighiaceae, Plantaginaceae, and Krameriaceae; but none have been reared and managed for pollination purposes so far (Roubik 1992; Freitas et al. 1999).

Acerola or West Indian cherry (Malpighia emarginata D.C.) is a Malpighiaceae originating from the Antilles, Central America, and Northern South America cultivated mainly for its vitamin C-rich fruit primarily in Brazil, Cuba, Puerto 
Rico, and USA (Oliveira and Schlindwein 2009). Acerola flowers bear six to 10 large sessile oilproducing glands (epithelial elaiophores) in the calyx that attract Centridini bees to visit them, making the oil-collecting bees their main pollinators (Freitas et al. 1999; Vilhena et al. 2012). Recently, Oliveira and Schlindwein (2009) have installed trap nests in an acerola orchard to be colonized by females of Centris (Heterocentris) analis Fabricius and proposed this bee species as a potentially manageable pollinator for $M$. emarginata because it accepts trap nests easily, presents prolonged yearly activity period and multivoltine life history. Also, Guedes et al. (2011) demonstrated that acerola orchards may face a strong pollination deficit in periods of the year when the native populations of Centris bees decrease. These studies, however, were carried out with wild Centridini populations naturally occurring in the area and did not measure pollination effectiveness in fruit yield. In our study, we introduced inhabited nests of a Centris species to acerola orchards for pollination purpose aiming to use its pollination services to mitigate pollination deficits and increase crop yield providing real gains in productivity.

\section{MATERIAL AND METHODS}

The experiment was carried out from October to December 2010 in the Amway Nutrilite do Brasil farm situated in the state of Ceará, Brazil. We chose two organic plantations (A and B) situated $2 \mathrm{~km}$ apart from each other and bearing 13-year-old trees. Each plantation comprised 15 ha of acerola subdivided in 22 orchards of 0.68 ha each planted with four acerola varieties: AC71 (eight orchards in each plantation), FP19 (six orchards), AC69 (four orchards), and AC13/2 (four orchards). These varieties are similar in most plant characters such as leave shape and color (elongated, dark green), canopy (vertical and horizontal equidistant), tree height (3.5-4.5 $\mathrm{m}$ for AC71 and 2.5-3.5 m for the others), flower (same color, size, and shape), blooming (all year round), and water and light demand (moderate and high, respectively). The varieties diverge mainly in average fruit size and weight (AC69, $4.49 \mathrm{~g}$; AC71, 4.63 g; AC13/2, 7.03 g; FP19, 8.81 g), pulp content (AC69, 7.33; AC71, 12.00; AC13/2, 8.00; FP19, 9.33), and Brix value (AC69, 7.07; AC71, 6.60; $\mathrm{AC} 13 / 2,7.07$; FP19, 7.50).

Surroundings and fruit productivity of both plantations were similar, varying from $0.94 \pm 0.23$ to $2.00 \pm$ $0.47 \mathrm{~kg} /$ plant in 2008 and 2009 for the same period of time and months of this study (refer to Online Resource 1 for details about the plantations and orchards layout).

The experiment consisted of three phases:

(a) Learning about the diversity of floral visitors in acerola plantations

Diversity of floral visitors was assessed using sweep nets to sample any visitor to acerola flowers in each plantation (A and B). An orchard per plantation was randomly chosen and a 50-m long transect was set in each orchard. Then, these transects were walked at every $3 \mathrm{~h}$, from 6:00 to 18:00 hours for six nonconsecutive days in October 2010.

(b) Using acerola plantations to multiply the population of oil-colleting bees

We distributed 14 empty trap nest blocks $(1,344$ trap nest holes) all over the farm to be colonized by Centridini bees before acerola blooming in plantations A and B. Trap nests were made by $8 \times$ $150 \mathrm{~mm}$ grooves drilled in pieces of wood $(140 \times$ $150 \mathrm{~mm}$ ) which were placed one on the top of the other to form a block up to seven stacks high. Each nesting block (a, b, c ... up to n) had 96 trap nests distributed in 16 columns and six lines. The 14 blocks had a total of 1,344 trap nests.

Centris analis is a multivoltine species and after the nests had been colonized and adult females had sealed them, the trap nest blocks containing only the sealed nests were introduced to plantation A. Due to the uneven colonization by the bees, some blocks had a smaller number of occupied nests than others, and some have none when the trap nest blocks were introduced in the orchards of plantation A. For this reason, the spatial distribution of the occupied/unoccupied trap nests was done at random, by means of a draw. The bees emerging from these introduced nests recolonized the trap nest blocks.

(c) Using oil-colleting bees to improve acerola yield We compared fruit yield from the 22 orchards where inhabited trap nests were introduced 
(plantation A), to that of the 22 orchards where no trap nests were placed (plantation B). During the experiment, fruits were manually harvested in a daily bases and the individual tree fruit production was recorded to allow comparisons per orchard, variety and area between plantations. Additional information on Section 2 are given in Online Resource 1.

\section{DATA ANALYSES}

The effect of introducing inhabited nests of Centris bees to acerola crop was assessed comparing independently yields from the four varieties existing in plantations $\mathrm{A}$ and $\mathrm{B}$, having as replicates the yield per tree and yield per area within each variety. Statistical analyses were carried out using ANOVA and means were compared a posteriori by Tukey's tests ( $5 \%$ ).

\section{RESULTS}

1. Learning about the diversity of floral visitors in acerola plantations

Floral visitors were scarce to acerola flowers in both plantation A and B. In plantation A, only 42 bees were collected of which 27 were Centridini bees. In the orchards of plantation B, 156 individuals were collected, but only 17 were Centridini bees (Table I).

Five Centris bee species were sampled in the plantations, but $C$. analis was the only Centridini bee found in the areas that nests in preestablished cavities and could be used in trap nests for pollination purposes (Table I).

2. Using acerola plantations to multiply the population of oil-colleting bees

Out of the 1,344 empty trap nests made available, $242(18 \%)$ were colonized by a single bee species, $C$. analis. After introduction of these inhabited trap nests to plantation $\mathrm{A}$, bees emerged, mated and began to forage in acerola flowers to establish new nests in the trap nest blocks. Three months later, by the end of the blooming season, bees had founded 394 new nests increasing $62.8 \%$ the original population. However, foundation of new nests was not uniform along the line in which trap nest blocks were distributed. In general, bees tended to found more nests in the blocks placed near the center of the block line and lessen nests near the plantation border (Table II).

3. Using oil-colleting bees to improve acerola yield

Trees of all the 22 orchards of plantation A produced significantly $\left(P<0.05 ; F_{1,43}=73\right.$, 23) more fruits than those of plantation $B$, independently of acerola variety (Table III). The same pattern was observed comparing the overall acerola tree yield $(4.84 \pm 0.37$ vs. $1.69 \pm 0.19 \mathrm{~kg} /$ tree $)$ and yield/ha (2.763 vs. $965 \mathrm{~kg} / \mathrm{ha}$; Table III).

Despite all four acerola varieties have improved yield significantly after the introduction of $C$. analis nests, varieties AC71, AC69 and FP19 were significantly $(P<$ $0.05 ; F_{1,15}=49.67, F_{1,7}=23.58, F_{1,11}=$ 21.71 , respectively) more productive and responded significantly better to the bee introduction than variety $\mathrm{AC} 13 / 2(P<0.05$; $F_{1,7}=13.80$ ).

\section{DISCUSSION}

The number of bees visiting the acerola flowers in the plantations was low. This result could be expected because acerola flowers do not produce nectar and are unattractive to most flower visitors due to overall low pollen production (Roubik 1992; Freitas et al. 1999). Centridini bees, however, need oil-producing flowers to feed their offspring and cannot establish a population where these flowers are not present (Oliveira and Schlindwein 2009).

In a large acerola plantation such as the one of this study, with oil-producing flowers in abundance, one would expect to find a variety of Centridini species and large number of bees. In our work, however, only few individuals of five Centris species were sampled. According to Cane (2001), bee nesting behavior and the environment surrounding plantations can interact determining the biodiversity of floral visitors 
Table I. Bee species floral visitors of acerola (M. emarginata D.C.) and their abundance in two organic plantations in Ubajara, state of Ceará, Brazil, 2010.

Bee species Bee abundance (individuals)

Plantation A

Plantation B

Apis mellifera Linnaeus 1758

9

Centris (Centris) aenea Lepelitier, 1841

6

13

Centris (Centris) flavifrons Fabricius, 1775

9

4

Centris (Heterocentris) analis Fabricius, 1804

9

Centris (Trachina) fuscata Lepelitier, 1841

2

0

Centris (Ptilotops) sponsa Smith, 1854

Trigona spinipes Fabricius, 1793

1

5

Xylocopa (Neoxylocopa) cearensis Ducke, 1910

Total

in an agricultural ecosystem. Centris bees obtained their nectar and pollen from plants other than acerola, and there were many flowering cashew and coconut trees blooming in the neighboring plantations, thus pollen and nectar were not a limiting resource (Fig. 1 of Online Resource 1). However, nesting sites seem to be the limiting factor for the establishment of larger Centris bee population in the areas studied. Trap nests displaced around the farm were quickly colonized by $C$. analis and nest numbers increased over $62 \%$ in only 3 months after being introduced to a acerola plantation. Considering the average of 3.8 brood cell/nest built by $C$. analis in solid blocks found by Oliveira and Schlindwein (2009), 342 nests mean, potentially, c.a. 3,000 new bees. Also, most nests were founded in the blocks placed near the center of the block line and the East border, where there were few potential nest sites in the agricultural setting. Few nests were founded near the West plantation border, where the vegetation can provide many nesting opportunities.

Besides rearing and increasing $C$. analis population, the introduction of inhabited trap nests to plantation A produced a significant increase in fruit productivity, to all the 22 orchards and varieties, in average over $286 \%$. Trees from plantation A produced on average $3.1 \mathrm{~kg}$ more fruits than on plantation $\mathrm{B}$, meaning an increment of 1.8 tons of fruits in the 15 ha of plantation A and an extra income of $\mathrm{U} \$ 2,250$ (U\$150/ha, present market price of $\mathrm{U}$ $\$ 1.25 / \mathrm{kg}$ ). This is an astonishing increment with potential implications from conquering new markets to ecological/environmental impacts on wild bees and native vegetation allowing

Table II. Number of nests of the oil-collecting bee $C$. (Heterocentris) analis per trap nest block introduced to and founded during the blooming of a acerola (M. emarginata DC.) organic plantation in Ubajara, state of Ceará, Brazil, 2010.

Trap nest blocks

\begin{tabular}{lcccccccccccccc}
\hline Nests & $\mathrm{A}$ & $\mathrm{B}$ & $\mathrm{C}$ & $\mathrm{D}$ & $\mathrm{E}$ & $\mathrm{F}$ & $\mathrm{G}$ & $\mathrm{H}$ & $\mathrm{I}$ & $\mathrm{J}$ & $\mathrm{K}$ & $\mathrm{L}$ & $\mathrm{M}$ & $\mathrm{N}$ \\
\hline Introduced & 9 & 50 & 68 & 12 & 0 & 27 & 1 & 0 & 20 & 0 & 0 & 0 & 29 & 26 \\
Founded & 7 & 36 & 74 & 22 & 15 & 56 & 5 & 22 & 33 & 30 & 9 & 1 & 34 & 47 \\
Increment & -2 & -14 & +6 & +10 & +15 & +29 & +4 & +22 & +13 & +30 & +9 & +1 & +5 & +21 \\
\hline
\end{tabular}


Table III. Average productivity of acerola (M. emarginata DC.) trees from organic plantations with and without the introduction of trap nests inhabited by the oil-collecting bee C. (Heterocentris) analis in Ubajara, state of Ceará, Brazil, 2010.

\begin{tabular}{|c|c|c|c|c|}
\hline Variety & Orchard & $\begin{array}{l}\text { Plantation with } \\
\text { C. analis nests }(\mathrm{kg} / \text { tree })\end{array}$ & $\begin{array}{l}\text { Plantation without } \\
\text { C. analis nests }(\mathrm{kg} / \mathrm{tree})\end{array}$ & $\begin{array}{l}\text { Difference between } \\
\text { plantations }(\mathrm{kg})\end{array}$ \\
\hline AC 71 & 01 & $4.61 \pm 0.37$ & $1.70 \pm 0.20$ & 2.91 \\
\hline AC 71 & 02 & $4.16 \pm 0.29$ & $2.40 \pm 0.31$ & 1.76 \\
\hline AC 71 & 03 & $6.64 \pm 0.45$ & $2.58 \pm 0.33$ & 4.06 \\
\hline AC 71 & 04 & $4.00 \pm 0.26$ & $3.00 \pm 0.41$ & 1.00 \\
\hline AC 71 & 05 & $5.31 \pm 0.41$ & $1.18 \pm 0.11$ & 4.13 \\
\hline AC 71 & 06 & $7.58 \pm 0.66$ & $1.66 \pm 0.18$ & 5.92 \\
\hline AC 71 & 07 & $5.12 \pm 0.39$ & $1.56 \pm 0.23$ & 3.56 \\
\hline AC 71 & 08 & $5.99 \pm 0.43$ & $1.34 \pm 0.14$ & 4.65 \\
\hline Average yield & - & $5.42 \pm 0.43 \mathrm{a}, \mathrm{A}$ & $1.92 \pm 0.22 \mathrm{~b}, \mathrm{~A}$ & $3.49 \pm 0.55 \mathrm{~A}$ \\
\hline FP 19 & 01 & $4.64 \pm 0.59$ & $1.65 \pm 0.19$ & 2.99 \\
\hline FP 19 & 02 & $3.97 \pm 0.48$ & $2.47 \pm 0.30$ & 1.50 \\
\hline FP 19 & 03 & $5.45 \pm 0.70$ & $2.56 \pm 0.36$ & 2.89 \\
\hline FP 19 & 04 & $7.63 \pm 0.76$ & $1.18 \pm 0.13$ & 6.45 \\
\hline FP 19 & 05 & $5.20 \pm 0.67$ & $1.67 \pm 0.25$ & 3.53 \\
\hline FP 19 & 06 & $3.05 \pm 0.39$ & $1.55 \pm 0.17$ & 1.50 \\
\hline Average yield & - & $4.99 \pm 0.63 \mathrm{a}, \mathrm{A}$ & $1.84 \pm 0.22 \mathrm{~b}, \mathrm{~A}$ & $3.14 \pm 0.74 \mathrm{~A}$ \\
\hline AC 69 & 01 & $6.65 \pm 0.71$ & $1.70 \pm 0.26$ & 4.95 \\
\hline AC 69 & 02 & $3.87 \pm 0.44$ & $3.04 \pm 0.62$ & 0.83 \\
\hline AC 69 & 03 & $5.31 \pm 0.62$ & $1.63 \pm 0.23$ & 3.68 \\
\hline AC 69 & 04 & $5.15 \pm 0.54$ & $1.34 \pm 0.20$ & 3.81 \\
\hline Average yield & - & $5.24 \pm 0.56 \mathrm{a}, \mathrm{A}$ & $1.92 \pm 0.37 \mathrm{~b}, \mathrm{~A}$ & $3.31 \pm 0.87 \mathrm{~A}$ \\
\hline $\mathrm{AC} 13 / 2$ & 01 & $7.63 \pm 0.32$ & $0.96 \pm 0.18$ & 6.67 \\
\hline $\mathrm{AC} 13 / 2$ & 02 & $1.66 \pm 0.14$ & $1.55 \pm 0.39$ & 0.11 \\
\hline $\mathrm{AC} 13 / 2$ & 03 & $2.48 \pm 0.35$ & $1.34 \pm 0.27$ & 1.14 \\
\hline $\mathrm{AC} 13 / 2$ & 04 & $3.19 \pm 0.43$ & $0.58 \pm 0.09$ & 2.61 \\
\hline Average yield & - & $3.74 \pm 1.33 \mathrm{a}, \mathrm{B}$ & $1.10 \pm 0.21 \mathrm{~b}, \mathrm{~B}$ & $2.63 \pm 1.44 \mathrm{~B}$ \\
\hline Overall average yield & - & $4.84 \pm 0.37 \mathrm{a}$ & $1.69 \pm 0.19 \mathrm{~b}$ & $3.14 \pm 0.18$ \\
\hline Fruit yield (kg/ha) & - & $2,763 \mathrm{a}$ & $965 \mathrm{~b}$ & 1,798 \\
\hline
\end{tabular}

Means followed by different lowercase letters in rows and uppercase letters in columns differ at $P<0.05$

reduction of cropped area or preventing deforestation of new areas to increase production (Freitas et al. 2009).

Our results suggest that the whole agricultural system in the farm was under a strong pollination deficit, as defined by Vaissière et al. (2011), alleviated in plantation A by the introduction of the $C$. analis nests. Pollination deficit has not been taken in consideration in most previous studies of acerola pollination, but apparently is a common problem in acerola plantations and becomes more severe in periods of the year when the native populations of Centris bees decrease (Guedes et al. 2011).

In the present work, we not only demonstrated to be feasible rearing and managing populations of $C$. analis for pollination of $M$. emarginata, as suggested by Oliveira and Schlindwein (2009), 
but also produced the first evidence that introducing inhabited nests of a Centris species to acerola orchards for pollination purpose may mitigate pollination deficits and increase crop yield providing real gains in productivity. Further studies are needed to determine the ideal bee frequency to flower and bee/nest density in the orchards.

\section{ACKNOWLEDGMENTS}

Authors thank Dr. Fernando Zanella for identification of the Centridini bees; Amway Nutrilite do Brasil for permission to carry out this study in its farm; two anonymous referees for their substantial contribution to this paper and National Council for Scientific and Technological Development-CNPq, Brasília-Brazil for the M.Sc. scholarship to C. B. Magalhães and the research fellowship to B.M. Freitas (proc. \#302934/2010-3).

Augmentation de la récolte de fruits dans les vergers d'acerola (Malpighia emarginata) grâce à l'introduction de nids artificiels pour l'abeille récolteuse d'huile, Centris analis (Hymenoptera: Apidae: Centridini)

Élevage d'abeilles / pollinisation des cultures / déficit en pollinisation / abeilles solitaires/ nid-piège

Die Einführung von nestern der ölsammelnden Biene Centris analis (Hymenoptera: Apidae: Centridini) zur Bestäubung erhöht den Ertrag von Acerola-Kirschen (Malpighia emarginata)

\section{Bienenaufzucht / Bestäubung / Bestäubungsdefizit / Sölitärbienen / Nisthilfen}

\section{REFERENCES}

Cane, J.H. (2001) Habitat fragmentation and native bees: a premature verdict? Conserv. Ecol. 5(1), 3

Free, J.B. (1993) Insect pollination of crops, p. 684p. Cardiff University Press, London

Freitas, B.M., Alves, J.E., Brandão, G.F., Araujo, Z.B. (1999) Pollination requirements of West Indian cherry (Malpighia emarginata) and its putative pollinators, Centris bees, in NE Brazil. J. Agr. Sci 133, 303-311

Freitas, B.M., Imperatriz-Fonseca, V.L., Medina, L.M., Kleinert, A.M.P., Galetto, L., Nates-Parra, G., Quezada-Euán, J.J.G. (2009) Diversity, threats and conservation of native bees in the Neotropics. Apidologie 40(3), 332-346

Guedes, R.S., Zanella, F.C.V., Martins, C.F., Schlindwein, C. (2011) Déficit de polinização da aceroleira no período seco no semiárido paraibano. Rev. Bras. Frutic. 33(2), 465-471

Oliveira, R., Schlindwein, C. (2009) Searching for a manageable pollinator for Acerola orchards: the solitary oil-collecting bee Centris analis (Hymenoptera: Apidae: Centridini). J. Econ. Entomol. 102(1), 265273

Roubik, D.W. (1992) Ecology and natural history of tropical bees. Cambridge University Press, Cambridge. $514 \mathrm{p}$

Vaissière B.E., Freitas B.M.; Gemmill-Herren B. 2011. Protocol to detect and assess pollination deficits in crops: a handbook for its use, Rome: FAO, $81 \mathrm{p}$

Vicens, N., Bosch, J. (2000) Pollinating efficiency of Osmia cornuta and Apis mellifera (Hymenoptera: Megachilidae, Apidae) on 'Red Delicious'apple. Popul. Ecol. 29, 235-240

Vilhena, A.M.G.F., Rabelo, L.S., Bastos, E.M.A.F., Augusto, S.C. (2012) Acerola pollinators in the savanna of Central Brazil: temporal variations in oilcollecting bee richness and a mutualistic network. Apidologie 43(1), 51-62 